\title{
Etika Psikolog dalam Pengumpulan dan Penyampaian Hasil Pemeriksaan Psikologis (Tinjauan Aksiologi)
}

\author{
Windar Ningsih', Siti Urbayatun² \\ Magister Psikologi Profesi, Universitas Ahmad Dahlan, Yogyakarta, Indonesia \\ E-mail: windar2007043020@webmail.uad.ac.id ${ }^{1}$, siti.urbayatun@psy.uad.ac.id ${ }^{2}$
}

\begin{abstract}
Abstrak
Dalam pandangan filsafat, etika adalah suatu nilai dan evaluasi tentang baik buruknya diri manusia, etika juga merupakan bagian dari kajian aksiologi. Setiap ilmu memiliki kajian aksiologi yang bertujuan untuk pemanfaatan dalam kemakmuran hidup manusia. Etika ini akan membantu semua pihak merasa nyaman dan terlindungi ketika sedang menggunakan jasa pelayanan dari profesi psikolog. Penelitian ini bertujuan untuk mendeskripsikan etika psikolog dalam pengumpulan dan penyampaian hasil pemeriksaan psikologis. Metode penelitian yang digunakan adalah kajian pustaka, artikel dikumpulkan dengan menggunakan mesin pencari seperti EBSCO, Sciencedirect, Google Scholar dan buku kode etik oleh HIMPSI. Hasil penelitian ini menunjukkan bahwa etika psikolog dalam pengumpulan dan penyampaikan hasil pemeriksaan psikologis dapat berupa menjaga kerahasiaan data, pertanggungjawaban data dan memahami batas kerahasiaan data. Kesimpulan penelitian ini dalam praktik psikologi etika sangatlah penting karena jika terjadi pelanggaran dari etika sangat mungkin pasien akan merasakan rasa malu, tidak berharga, atau beban-beban psikologis lainnya. Penelitian ini dapat digunakan dalam menjelaskan bahwa nilai profesionalisme seorang psikolog terletak pada etika dalam pengumpulkan dan penyampaikan hasil psikologis.
\end{abstract}

Kata Kunci: etika; psikolog; aksiologi.

\section{Abstract}

In a philosophical view, ethics is an assessment and evaluation of the merits of humans, ethics is also a part of axiological studies. Each science has axiological studies that aim to benefit from the prosperity of human life. This ethic will help all parties who feel comfortable and protected when using the services of the psychologist profession. This study aims to describe the ethics of psychologists and to convey the results of psychological examinations. The research method used is literature review, articles collected using search engines such as EBSCO, Sciencedirect, Google Scholar, and the code of ethics book by HIMPSI. The results of this study indicate that the ethics of psychologists in reporting and conveying psychological results can be in the form of maintaining data confidentiality, data accountability and understanding the limits of data confidentiality. The conclusion of research in ethical psychology is very important because if the practice of ethics occurs, it is very likely that the patient will feel shame, worthlessness, or other psychological burdens. This research can be used to explain that the value of a psychologist's professionalism lies in the ethics of collecting and submitting psychological results.

Keywords: ethics; psychologist; axiology.

\section{Pendahuluan}

Salah satu pilar utama dalam filsafat ilmu yang selalu menjadi pedoman adalah aksiologi. Setelah memperoleh pengetahuan manfaat apa yang bisa digunakan dari pengetahuan itu adalah sebuah pemikiran yang menuju konsep aksiologi. Aksiologi adalah bagian filsafat yang membahas masalah nilai kegunaan dari nilai pengetahuan dan sifat, watak serta kebiasaan merupakan istilah yang merujuk pada etika. Objek material etika adalah tingkah laku atau perbuatan manusia berupa perbuatan yang dilakukan secara sadar dan bebas, sedangkan objek formal etika adalah kebaikan dan keburukan atau bermoral dan tidak bermoral dari tingkah laku tersebut (Suriasumantri, 1987). Penerapan etika sangat butuhkan dalam berbagai disiplin ilmu, salah satunya adalah ilmu psikologi. 
Objek kajian etika yang telah berusia sangat lama adalah moralitas manusia. Sejak manusia terbentuk, persoalan perilaku yang sesuai dengan moralitas telah menjadi bahasan. Bahasan etika, dalam sejarah filsafat barat sudah ada sejak jaman Sokrates. Dalam penjelasannya, etika tidak mempersoalkan apa atau siapa manusia itu, tetapi bagaimana manusia seharusnya bertindak atau berbuat sesuatu. Dalam filsafat penerapan pengetahuan ilmuwan meninjaunya dari segi aksiologi keilmuwan. Seorang ilmuwan mempunyai tanggungjawan agar produk keilmuwannya sampai dan dapat dimanfaatkan dengan baik oleh masyarakat. Penerapan etika sangat butuhkan oleh ilmuwan salah satunya adalah ilmuwan psikologi (Abadi, 2016).

Psikologi adalah suatu ilmu sosial yang mempelajari tentang perilaku manusia dengan berbagai karakteristiknya sebagai pengetahuan yang didapatkan dari penelitian-penelitian ilmiah. Dari pendekatan ilmiah akan didapatkan kesimpulan yang sama pada setiap orang karena pendekatan tersebut tidak diwarnai oleh keyakinan, keinginan dan perasaan pribadi. Cara pengambilan keputusan tidak secara subyektif tetapi dengan objektif, oleh sebab itu sifat objektif akan selalu dituntut dalam suatu ilmu (Nursalim, 2017). Aliran Yunani menjelaskan bahwa bentuk tertinggi dari ilmu adalah kebijaksanaan, di sini terlihatlah suatu sikap etika. Mempelajari IImu selalu diperlukan kejujuran yaitu kejujuran ilmiah. Hasil yang didapatkan dari ilmu harus dilaporkan apa adanya, kalau negatif harus dikatakan negatif. Kajian ilmiah harus didasarkan pada kejujuran dan biasanya penuh dengan kata-kata yang batasannya jelas dan tegas sehingga apa yang ingin disampaikan tidak mudah disalah interpretasikan (Suriasumantri, 1992).

Seorang psikolog dapat melakukan pemeriksaan psikologi. Pemeriksaan psikologi adalah suatu rangkaian kegiatan yang berguna dalam masyarakat untuk berbagai kepentingan. Dalam dunia industri dan organisasi, pemeriksaan psikologi umumnya dilakukan untuk kepentingan seleksi, penempatan karyawan, maupun promosi jabatan. Sedangkan dalam lingkungan pendidikan, pemeriksaan psikologis dilakukan sebagai upaya penentuan minat dan bakat siswa, serta mengetahui kapasitas intelektual dari siswa dengan berbagai macam tujuan. Salah satu yang menjadi tujuannya adalah untuk memprediksi tingkat keberhasilan siswa dalam belajar. Sementara dalam ranah klinis atau sosial, pemeriksaan psikologis merupakan salah satu pertimbangan dalam menentukan jenis terapi aau intervensi tertentu yang dapat membantu individu untuk berfungsi lebih baik ke kehidupannya sehari-hari. Tujuan pemeriksaan psikologis adalah untuk mendapatkan suatau hasil pemeriksaan maupun evaluasi yang memadai (Suwartono, 2020).

Salah satu penekanan nilai profesionalisme seorang psikolog terletak pada etika dalam menyampaikan hasil pemeriksaan psikologis dengan menjaga kejujuran dan kerahasiaan data. Jaminan yang sering kali di berikan kepada klien adalah bahwa keterbukaan dan segala informasi yang disampaikan dalam sesi terapi atau konseling akan terjaga kerahasiannya dan hasil yang disampaikan oleh psikolog benar adanya (Himawan dkk, 2016). Kerahasiaan data adalah suatu keharusan utama yang harus di perhatikan dan diprioritaskan oleh para praktisi kesehatan mental. Kerahasiaan bahkan oleh para psikolog dianggap sebagai kewajiban etis yang terpenting. Namun berdasarkan pada penelitian terhadap psikolog secara nasional banyak ditemukan pelanggaran yang disengaja yang paling sering dilakukan, seperti membuka hasil pemeriksaan psikologi klien di persidangan maupun di publik. Walaupun, lebih dari separuh responden melaporkan mereka melanggar kerahasiaan secara tidak sengaja (Corey dkk, 2011). Seorang psikolog yang melakukan atau menyebarkan inforamasi tanpa persetujuan mendapatkan sanksi dari undangundang atau peraturan pemerintah Kode Etik yang telah ditentukan (Koocher, 2014).

Berdasarkan penjelasan diatas, penulis berusaha untuk menganalisis permasalahan terkait etika psikolog dalam pengumpulan dan penyampaian hasil pemeriksaan psikologis. Ada beberapa uraian penting dalam kajian ini, yaitu pemahaman tentang etika serta etika dalam pengumpulan dan penyampaian hasil pemeriksaan psikologi. Penelitian ini diharapkan dapat memberikan pemahaman etika hasil pemeriksaan psikologis serta relevansinya bagi pengembangan ilmu psikologi dan filsafat di Indonesia.

\section{Metode}

Metode yang digunakan dalam artikel ini adalah kajian Pustaka dengan menggunakan buku dan artikel jurnal yang relevan yaitu referensi memuat topik tentang etika psikolog (Faizah, 2020). Analisis yang digunakan di dalam metode ini adalah analisis isi. Bengtsson (2016) menjelaskan analisis isi berupa membentangkan, mengaitkan, dan menemukan benang merah 
dari berbagai literatur untuk menyajikan fokus utama artikel ini. Pertama, mengidentifikasi berbagai sumber literatur untuk kepentingan penulisan artikel. Kedua, melakukan teknik analisis isi untuk menemukan benang merah dari berbagai literatur dengan selalu memperhatikan fokus utama penulisan artikel. Ketiga, menarik kesimpulan dan saran bagi pengembangan etika dalam pengumpulan dan penyampaikan hasil pemeriksaan psikologis.

\section{Hasil dan Pembahasan a. Etika}

Istilah etika sangat dekat dengan "moral". Kata ini berasal dari bahasa Latin "Mos" yang artinya kebiasaan atau adat. Jadi, secara etimologi kata etika sama dengan etimologi kata "moral", karena keduanya berasal dari kata yang bearti adat kebiasaan (Dewantara, 2018). Para ahli menggali nila-nilai etika di dalam kehidupan baik antar individu maupun masyarakat dan dari nilainilai itulah etika menjadi pedoman perilaku manusia (etiket), kemudian didalami sebagai ilmu (pengetahuan), namun etika juga dapat menjadi aturan bagi sekelompok orang dalam suatu pekerjaan (profesi) atau dikenal dengan kode etik (ethic of conduct) (Siregar, 2015).

Etika merupakan filsafat tentang nilai, kesusilaan, tentang baik dan buruk. Selain etika mempelajari nilai-nilai, juga merupakan pengetahuan tentang nilai-nilai itu sendiri (Lubis, 1994). Ada juga yang menyebutkan bahwa etika adalah bagian dari filsafat yang mengajarkan keseluruhan budi (baik dan buruk). Etika ialah tentang filsafat moral, tidak mengenai fakta, tetapi tentang nilai-nilai, tidak mengenai tindakan manusia, tetapi tentang idenya. Etika juga studi tentang tingkah laku manusia, tidak hanya menentukan kebenarannya sebagaimana adanya, tetapi juga menyelidiki manfaat atau kebaikan dari seluruh tingkah laku yang dilakukan manusia (Verhaak \& Imam, 1991).

Konsep etika sebagai bidang kajian filsafat, khususnya filsafat moral mengatakan bahwa etika sudah sangat lama menjadi wacana intelektual para filsuf. Etika telah menjadi pusat perhatian sejak jaman yunani kuno. Sampai saat ini pun etika masih tetap menjadi bidang kajian menarik dan aktual. Bahkan dianggap semakin penting untuk tidak sekedar dibicarakan di kalangan akademik melainkan juga dipraktekkan dalam interaksi kehidupan sehari-hari setiap manusia (Wahid \& Muhibbin, 2009).

Etika selain dari pada bagian dari ilmu pengetahuan atau bagian dari filsafat ilmu, juga merupakan panduan dari nilai-nilai terhadap tata cara hidup bagi individu, masyarakat maupun bernegara. Setiap kehidupan itu perlu suatu etika agar nilai-nilai moralitas dapat terjaga di dalam kehidupan itu sendiri. Hubungan etika dengan ilmu merupakan pembatasan agar pemikiran manusia yang haus akan kebenaran dapat terjaga tidak keluar dari norma-norma yang seharusnya tetap dipertahankan karena itulah akal yang dibebaskan akan mengarah kepada kesesatan (Ali, 2006).

Penjelasan di atas menyajikan hubungan antara etika dan ilmu, di mana berawal dari perilaku manusia yang pada hakekatnya etika dan moral itu memiliki pengertian atau pemahaman yang sama. Kedua istilah ini mengandung arti perilaku yang baik dari seseorang atau sekelompok orang sebagai pedoman dari tuntutan hati nurani orang yang bersangkutan dan masyarakat demi untuk terciptanya rasa kemanusiaan, kejujuran dan keadilan dalam kehidupan antar individu dan masyarakat (Yuwono, 2011)

IImu bukanlah tujuan tetapi sarana untuk mencapai hasrat akan kebenaran yang berhubungan dengan etika bagi sesama manusia dan tanggung jawab secara agama. Sebenarnya ilmuwan dalam gerak kerjanya perlu mengaitkan secara utuh antara adanya dua faktor, yaitu ilmu dan tanggung jawab, karena yang kedua itu melekat dengan yang pertama. Dengan tanggung jawab itu berarti ilmuwan mempunyai etika dalam keilmuannya itu. Ilmu yang melekat dengan keberadaban manusia yang terbatas, maka dengan ilmu hasrat keingintahuan manusia yang terdapat di dalam dirinya merupakan petunjuk mengenai kebenaran yang transeden di luar jangkauan manusia (Siregar, 2015)

Etika penelitian adalah suatu ukuran dari tingkah laku dan perbuatan yang harus dilakukan atau diikuti oleh seorang peneliti dalam memperoleh dan mengumpulkan data-data penelitiannya yang disesuaikan dengan adat istiadat serta kebiasaan masyarakat ditempat ia meneliti (Yuwono, 2011). American Psychological Association atau APA telah menyusun etika penelitian psikologi. Terdapat 12 etika penelitian yang telah disusun yaitu Instituional, Informed consent for research, Informed consent for recording, Client/patient, student and subordinate research participants, Dispensing with informed consent, Offering inducements for research participation, Deception in 
research, Debriefing, Humane care and use of animals in research, Reporting research results, Plagiarism, Publication Credit, Duplicate publication of data, Sharing research data for verification, dan Obligations on review (Hunsley \& Lee, 2014).

\section{b. Etika Psikolog Dalam Pengumpulan dan Penyampaian Hasil Pemeriksaan Psikologis}

Etika profesi adalah karakteristik suatu profesi yang membedakan profesi satu dengan profesi lain, yang berfungsi untuk mengatur tingkah laku anggotanya. Setiap profesi yang memberikan pelayanan jasa kepada masyarakat harus memiliki kode etik. Kode etik merupakan seperangkat prinsip-prinsip moral yang mengatur tentang perilaku profesional (Abadi, 2016). Profesi psikolog memberikan layanan psikologi yang mengharuskannya berhubungan langsung dengan klien, maka disamping patuh kepada kode etik ilmu pengetahuan pokok-pokok etika profesi, psikolog umumnya bertanggung jawab untuk memberikan perlindungan bagi ilmu pengetahuan agar terjaga eksistensinya, semakin tumbuh dan bermanfaat bagi masyarakat. Psikolog juga harus memberikan perlindungan bagi praktisi ilmu pengetahuan agar optimal, tumbuh dan berkembang mengamalkan profesinya. Selanjutnya, memberikan perlindungan bagi masyarakat yang menjadi klien agar terhindar dari hak-hal yang merugikan akinat penggunaan yang salah dari pemeriksaan psikologi (Kirana, 2020).

Dalam membangun kepercayaan masyarakat untuk menghargai profesi psikolog, maka diperlukan kepastian jaminan perwujudan dari upaya meningkatkan kesejahteraan psikologi bagi seluruh masyarakat dan tata nilainya yang dibuat oleh komunitas psikologi. Sehingga HIMPSI sebagai satu-satunya wadah komunitas psikologi di Indonesia, telah menghimpun nilai-nilai moral yang hakiki dalam bentuk Kode Etik Psikologi Indonesia yang berfungsi sebagai standar pengaturan diri bagi Psikolog dan IImuwan Psikologi. Hal ini bertujuan untuk memberikan pelayanan kepada masyarakat, Kode Etik Psikologi hakikatnya merupakan kristalisasi dari nilai moral yang brsifat universal, sehingga penyusunannya juga mempertimbanhkan kesepakatan internasional (Himawan dkk, 2016).

Keberadaan kode etik profesi memiliki fungsi untuk menjamin kepercayaan masyarakat bahwa mereka akan diperlakukan berdasarkan tujuan layanan yang diselenggarakan. Kehadiran kode etik berfungsi seperti kompas yang menunjukkan arah moral bagi suatu profesi dan sekaligus menjamin mutu moral profesi itu sendiri di mata masyarakat (Pedhu, 2020)

Seorang psikolog yang melakukan atau menyebarkan informasi tanpa persetujuan mendapatkan sanksi dari undang-undang atau peraturan pemerintah kode etik yang telah ditentukan (Koocher, 2014). Himpunan Psikologi Indonesia (HIMPSI) telah menetapkan pasalpasal penting dalam penerapan kode etik Psikologi sebagai psikolog profesional di Indonesia. Pasal 17 merupakan salah satu kode etik dari HIMPSI yang bertajuk "konflik kepentingan". Pasal tersebut berisikan bahwa Psikolog dan IImuwan Psikologi menghindar dari melakukan peran profesional apabila kepentingan pribadi, ilmiah, profesional, hukum, finansial, kepentingan atau hubungan lain diperkirakan akan merusak objektivitas, kompetensi, atau efektivitas mereka dalam menjalankan fungsi sebagai psikolog dan IImuwan psikologi atau berdampak buruk bagi pengguna layanan psikologi serta pihak-pihak yang terkait dengan pengguna layanan psikologi tersebut.

Peran dan pengaruh etika dalam kegiatan pemeriksaan psikologi sangat penting. Psikolog, dan para pekerja sosial lainnya yang menyelenggarakan kegiatan- kegiatan psikologi perlu memahami nilai-nilai, etika, moral, dan hukum. Hal ini disebabkan karena psikolog dan ilmuwan psikologi yang tidak memahami nilai - nilai, etika, dan tanggung jawab legal klien, dapat menyebabkan kerugian dari niat dan tujuan baik terhadap layanan yang diselenggarakan (Gladding, 2012)

Pelanggaran kode etik didunia psikologi kerap kali terjadi dalam penanganan kasuskasus fenomena sosial yang ada di Indonesia. Salah satu kasus fenomena sosial yang terkait dalam topik ini adalah pelanggaran kode etik oleh ahli psikologi Antonia Ratih Andjayani. Pelanggaran yang dilakukan adalah mempublikasikan hasil tes tanpa adanya persetujuan dari pihak kedua dalam sidang kasus pembunuhan Wayan Mirna Salihin. Mengumbar hasil ke publik telah melanggar aturan kode etik psikolog. Hasil analisis kejiwaan seseorang dalam kasus ini Jessica bersifat rahasia dan hanya dapat dibuka atas izin pengadilan.

Kasus-kasus pelanggaran dapat ditemukan pada praktik psikologi juga dapat dilakukan oleh orang-orang yang tidak mempunyai kualifikasi yang sesuai dan diakui oleh pendidikan psikologi yang ada dan telah terakreditasi. Hal ini dapat berakibat sangat membahayakan, karena bisa berakibat pemberian saran yang keliru dan tidak profesional yang berdampak fatal bagi klien. 
Dampak dari pelanggaran yang dilakukan tersebut memungkinkan hasil tes atau pemeriksaan yang diberikan tidak sesuai dengan kondisi individu yang dites. Dalam bidang klinis dan pendidikan, asesmen yang tidak tepat pada individu berpeluang menimbulkan kesalahan intervensi terhadap individu tersebut. Dalam bidang Industri dan Organisasi, pelanggaran berpeluang untuk menempatkan seseorang yang tidak tepat atau sesuai antara uraian pekerjaan atau syarat pekerjaan dengan kompetensi yang dimiliki individu (Himpsi, 2018).

Etika psikolog dalam menyampaikan hasil pemeriksaan psikologi bisa dilihat dari bagaimana cara menjaga kerahasiaan klien dalam urusan pencatatan, penyimpanan, pemindahan dan pemusnahan catatan data di bawah pengawasan, yang bisa dalam bentuk tertulis atau lainnya. Kemudian hasil pemeriksaan psikologis dapat diberikan hanya kepada yang berwenang mengetahui dan hanya memuat hal-hal yang langsung dan berkaitan dengan tujuam pemeriksaan psikologis. Psikolog tidak dapat membuka kerahasiaan hasil pemeriksaan psikologis untuk keperluan penulisan, pengajaran, maupun pengungkapan di media, kecuali jika ada alasan kuat untuk itu dan tidak bertetangan dengan hukum (Kirana, 2020).

\section{Simpulan dan Saran}

Berdasarkan penjelasan sebelumnya maka dapat disimpulkan bahwa etika profesi adalah sikap hidup berupa keadilan untuk memberikan pelayanan profesional terhadap masyarakat dengan penuh ketertiban dan keahlian sebagai pelayanan dalam rangka melaksanakan tugas berupa kewajiban terhadap masyarakat. Pelanggaran etika profesi merupakan pelanggaran yang dilakukan oleh sekelompok profesi yang tidak mencerminkan atau memberi petunjuk kepada anggotanya bagaimana seharusnya berbuat dan sekaligus menjamin mutu profesi itu dimata masyarakat. Idealisme yang terkandung dalam kode etik profesi tidak sejalan dengan fakta yang terjadi di sekitar para profesional, sehingga harapan terkadang sangat jauh dari kenyataan.

Profesional memiliki himpunan norma moral yang tidak dilengkapi dengan sanksi keras, tetapi harus di patuhi karena memiliki kesadaran profesional. Perlu perwujudan terbentuknya kultur dan kesadaran dari para pengemban profesi untuk menjaga martabat luhur masing-masing profesi. Kode etik profesi merupakan bagian dari etika profesi. Etika psikolog dalam pengumpulan dan penyampaian hasil pemeriksaan psikologis dapat berupa menjaga kejujuran dan kerahasiaan data, data yang disampaikan dapat dipertanggungjawabkan dan memahami batas kerahasiaan data.

Kode etik psikologi pasal tujuh belas juga menjelaskan bahwa Psikolog dan Ilmuwan Psikologi diharapkan dapat menghindar dari melakukan peran profesional apabila kepentingan pribadi, ilmiah, profesional, hukum, finansial, kepentingan atau hubungan lain yang diperkirakan akan merusak objektivitas, kompetensi, atau efektivitas dalam menjalankan fungsi sebagai psikolog dan Ilmuwan psikologi atau berdampak buruk bagi pengguna layanan psikologi serta pihak-pihak yang terkait dengan pengguna layanan psikologi tersebut. Hal ini bertujuan agar tidak terjadi pelanggaran kode etik yang dapat merugikan psikolog, ilmuwan psikologi dan masyarakat pengguna jasa pelayanan psikologi.

\section{Daftar Pustaka}

Abadi, T. W. (2016). Aksiologi: antara etika, moral, dan estetika. KANAL: Jurnal Ilmu Komunikasi, 4(2), 187. https://doi.org/10.21070/kanal.v4i2.1452

Ali, Z. (2006). Filsafat hukum. Jakarta: Sinar Grafika.

Bengtsson, M. (2016). How to plan and perform a qualitative study using content analysis. NursingPlus Open, 2, 8-14. https://doi.org/10.1016/j.npls.2016.01.001

Corey, G., Corey, M. S., \& Callaman, P. (2011). Issues and ethics in the helping professions. United States of America: Cengage Learning. https://doi.org/10.1007/BF03079201

Dewantara, A. (2018). Filsafat moral (pergumulan etis keseharian hidup manusia). Yogyakarta: Kanisius.

Faizah, U. (2020). Etika lingkungan dan aplikasinya dalam pendidikan menurut perspektif aksiologi. Filsafat Indonesia, 3(1), 14-22.

Gladding, S. T. (2012). Konseling profesi yang menyeluruh. Jakarta: Indeks.

Himawan, K. K., Dewi, W. P., Sitorus, K. S., \& Mutiara, E. (2016). Kode etik psikologi dan aplikasinya di indonesia. Jakarta: Salemba Humanika.

Hunsley, J., \& Lee, C. M. (2014). Clinical psychology: an evidence based approach. United States 
of America: John Wiley \& Sons, Inc.

Indonesia, H. P. (2018). Rancangan undang-undang profesi psikologi. In Himpunan Psikologi Indonesia.

Jujun S. Suriasumantri. (1987). Ilmu dalam perspektif. Jakarta: Gramedia.

Jujun S. Suriasumantri. (1992). Tentang hakekat ilmu. Jakarta: Yayasan Obor Indonesia.

Kirana, Y. (2020). Psikologi dan etika profesi dalam nilai-nilai ilmu pengetahuan. Jurnal Hukum dan Keadilan, 7, 130-149.

Koocher, G. P. (2014). Research ethics and private harms. Journal of Interpersonal Violence, 29(18), 3267-3276. https://doi.org/10.1177/0886260514534986

Lubis, S. K. (1994). Etika profesi hukum. Jakarta: Sinar Grafika.

Nursalim, M. (2017). Landasan ontologis, epistemologis, dan aksiologis dalam penelitian psikologi. Kalam, 7(2), 387. https://doi.org/10.24042/klm.v7i2.455

Pedhu, Y. (2020). Isu-isu etika penggunaan tes psikologi dalam bimbingan konseling. Seminar Nasional Daring IIBKIN.

Siregar, F. (2015). Etika sebagai filsafat ilmu (pengetahuan). Jurnal De'Rechtsstaat, 1(1), 54-61.

Suwartono, C. (2020). Alat tes psikologi konteks indonesia: tantangan psikologi di era MEA. Jurnal Psikologi Ulayat, 3(1), 1-6. https://doi.org/10.24854/jpu37

Verhaak, C., \& Imam, R. H. (1991). Filsafat ilmu pengetahuan : telaah atas cara kerja ilmu-ilmu. Jakarta: Gramedia Pustaka Utama.

Wahid, A., \& Muhibbin, M. (2009). Etika profesi hukum (rekonstruksi citra peradilan di indonesia). Malang: Banyumedia Publishing.

Yuwono, I. D. (2011). Memahami berbagai etika profesi dan pekerjaan. Yogyakarta: Pustaka Yusticia. 